\title{
KLASIFIKASI LAPORAN KELUHAN PELAYANAN PUBLIK BERDASARKAN INSTANSI MENGGUNAKAN METODE LDA-SVM
}

\author{
Muhammad Alkaff *1, Andreyan Rizky Baskara², Irham Maulani \\ ${ }^{123}$ Universitas Lambung Mangkurat, Banjarmasin \\ Email : ${ }^{1}$ m.alkaff@ulm.ac.id, ${ }^{2}$ andreyan.baskara@ulm.ac.id, ${ }^{3}$ irhammaulani@gmail.com \\ *Penulis Korespondensi
}

(Naskah masuk: 10 Juli 2021, diterima untuk diterbitkan: 17 November 2021)

\begin{abstract}
Abstrak
Sebuah sistem layanan untuk menyampaikan aspirasi dan keluhan masyarakat terhadap layanan pemerintah Indonesia, bernama Lapor! Pemerintah sudah lama memanfaatkan sistem tersebut untuk menjawab permasalahan masyarakat Indonesia terkait permasalahan birokrasi. Namun, peningkatan volume laporan dan pemilahan laporan yang dilakukan oleh operator dengan membaca setiap keluhan yang masuk melalui sistem menyebabkan sering terjadi kesalahan dimana operator meneruskan laporan tersebut ke instansi yang salah. Oleh karena itu, diperlukan suatu solusi yang dapat menentukan konteks laporan secara otomatis dengan menggunakan teknik Natural Language Processing. Penelitian ini bertujuan untuk membangun klasifikasi laporan secara otomatis berdasarkan topik laporan yang ditujukan kepada instansi yang berwenang dengan menggabungkan metode Latent Dirichlet Allocation (LDA) dan Support Vector Machine (SVM). Proses pemodelan topik untuk setiap laporan dilakukan dengan menggunakan metode LDA. Metode ini mengekstrak laporan untuk menemukan pola tertentu dalam dokumen yang akan menghasilkan keluaran dalam nilai distribusi topik. Selanjutnya, proses klasifikasi untuk menentukan laporan agensi tujuan dilakukan dengan menggunakan SVM berdasarkan nilai topik yang diekstraksi dengan metode LDA. Performa model LDA-SVM diukur dengan menggunakan confusion matrix dengan menghitung nilai akurasi, presisi, recall, dan F1 Score. Hasil pengujian menggunakan teknik split train-test dengan skor 70:30 menunjukkan bahwa model menghasilkan kinerja yang baik dengan akurasi 79,85\%, presisi 79,98\%, recall 72,37\%, dan Skor F1 74,67\%.
\end{abstract}

Kata kunci: lapor, laporan, topic modeling, klasifikasi, latent dirichlet allocation, support vector machine

\section{CLASSIFICATION OF PUBLIC SERVICE COMPLAINT REPORTS BASED ON AGENCY USING LDA-SVM METHOD}

\begin{abstract}
A service system to convey aspirations and complaints from the public against Indonesia's government services, named Lapor! The Government has used the Government for a long time to answer the problems of the Indonesian people related to bureaucratic problems. However, the increasing volume of reports and the sorting of reports carried out by operators by reading every complaint that comes through the system cause frequent errors where operators forward the reports to the wrong agencies. Therefore, we need a solution that can automatically determine the report's context using Natural Language Processing techniques. This study aims to build automatic report classifications based on report topics addressed to authorized agencies by combining Latent Dirichlet Allocation (LDA) and Support Vector Machine (SVM). The topic-modeling process for each report was carried out using the LDA method. This method extracts reports to find specific patterns in documents that will produce output in topic distribution values. Furthermore, the classification process to determine the report's destination agency carried out using the SVM based on the value of the topics extracted by the LDA method. The LDA-SVM model's performance is measured using a confusion matrix by calculating the value of accuracy, precision, recall, and F1 Score. The test results using the train-test split technique with a 70:30 show that the model produces good performance with $79.85 \%$ accuracy, $79.98 \%$ precision, $72.37 \%$ recall, and $74.67 \%$ F1 Score
\end{abstract}

Keywords: lapor, report, topic modeling, classification, latent dirichlet allocation, support vector machine 


\section{PENDAHULUAN}

Gerakan manajemen kualitas yang di pelopori oleh W. Edwads Deming seorang falsafah manajemen dengan manajemen mutu terpadu, selalu menganjurkan pentingnya orientasi terhadap pelanggan. Karena pelangganlah yang menentukan kualitas pada barang maupun jasa yang digunakan (Obsorne \& Gaebler, 1992). Orientasi terhadap pelanggan dalam konteks manajemen publik dimaknai secara luas adalah bagaimana birokrasi pemerintah dapat menghasilkan kebijakan publik (public interest) dan dapat di pertanggungjawabkan ke publik. Konsep pelanggan dalam pelayanan publik lebih tepat disebut dengan citizen atau warga negara. Warga negara berbeda dengan pelanggan, dimana pelanggan dapat berhenti terhadap suatu produk atau jasa yang tidak memuaskan. Sedangkan warga negara tidak memiliki pilihan lain selain menyampaikan keluhan dalam bentuk pengaduan (Saggaf, et al., 2018).

Pelayanan publik menjadi tolak ukur keberhasilan pelaksanaan tugas dan pengukuran kinerja pemerintah melalui birokrasi. Akan tetapi, fenomena pelayanan dan pengaduan publik oleh birokrasi pemerintah sarat dengan permasalahan. Misalnya, prosedur yang berlarut-larut, ketidakpastian waktu dan harga yang menyebabkan pelayanan menjadi sulit dijangkau (Maryam, 2016). Pengelolaan pengaduan pelayanan publik belum terkelola secara efektif dan terintegrasi. Masingmasing organisasi penyelenggara mengelola pengaduan secara parsial dan tidak terkoordinir dengan baik, akibatnya terjadi duplikasi dan aduan yang bukan masuk wewenang organisasi penyelenggara tersebut. Untuk itu pemerintah Republik Indonesia membentuk Sistem Pengelolaan Pengaduan Pelayanan Publik Nasional (SP4N) Layanan Aspirasi dan Pengaduan Online Rakyat (LAPOR!) (Kementerian Pendayagunaan Aparatur Negara dan Reformasi Birokrasi, n.d.).

Aplikasi Lapor! adalah layanan penyampaian semua aspirasi dan pengaduan masyarakat Indonesia melalui beberapa kanal pengaduan yaitu website www.lapor.go.id, SMS 1708, twitter@lapor1708 dan aplikasi smartphone android. Aplikasi Lapor! yang semula diinisasikan dan dikembangkan oleh Unit Kerja Presiden Bidang Pengawasan dan Pengendalian Pembangunan (UKPPPP atau UKP4) kini dikelola oleh Kementrian Pendayagunaan Aparatur Negara dan Reformasi Birokrasi (Kementrian PANRB). Lapor! telah ditetapkan sebagai Sistem Pengelolaan Pengaduan Pelayanan Publik Nasional (SP4N) berdasarkan Peraturan Presiden nomor 76 tahun 2013 dan Peraturan Menteri Pendayagunaan Aparatur Negara dan Reformasi Birokasi Nomor 3 tahun 2015 yang merealisasikan kebijakan no wrong door policy yang berarti menjamin pengaduan dari manapun dan jenis apapun akan disalurkan kepada penyelenggara pelayanan publik yang berwenang menanganinya
(Kementerian Pendayagunaan Aparatur Negara dan Reformasi Birokrasi, n.d.) (Megawati, 2015).

Aplikasi Lapor! telah terhubung dengan 34 Kementrian, 96 Lembaga, dan 493 Pemerintah daerah di Indonesia. Jumlah pelapor per Januari 2019 sebanyak 801.257 pengguna. Total laporan yang masuk sebanyak 1.389.891 yang terbagi dalam beberapa kanal Lapor!, dimana website sebagai kanal terbanyak dalam menampung laporan (Kementerian Pendayagunaan Aparatur Negara dan Reformasi Birokrasi, n.d.).

Kota Banjarmasin adalah salah satu kota di Indonesia dengan pertumbuhan pengguna aplikasi Lapor! yang tinggi, pada bulan Juli sampai Desember 2017 aplikasi Lapor! di kota Banjarmasin telah menjaring 115 laporan perharinya. Pada bulan Januari tahun 2019, laporan di Kota Banjarmasin tumbuh hingga 275 laporan perhari yang akan didisposisi ke semua instansi di Kota Banjarmasin yaitu 44 instansi yang dapat dilihat pada lampiran 2 . Dengan antusiasme warga yang tinggi serta kecepatan penyelenggara pelayanan publik dalam menindaklanjuti keluhan yang berasal dari aplikasi Lapor!, Kota Banjarmasin pun menerima penghargaan sebagai tiga kota terbaik pengguna aplikasi Lapor!. Pemerintah Kota Banjarmasin juga termasuk dalam 10 bagian dari kementrian negara, lembaga negara dan pemerintah daerah yang menjadi percontohan penerapan aplikasi Lapor! merujuk dari hasil monitoring yang dilakukan oleh Kementrian Pendayagunaan Aparatur Negara dan Reformasi Birokrasi dan Kantor Staf Presiden (Kementerian Pendayagunaan Aparatur Negara dan Reformasi Birokrasi, n.d.) ${ }^{1}$.

Berdasarkan data yang telah dipaparkan, dengan jumlah laporan khususnya di Kota Banjarmasin beserta jumlah instansi yang banyak tersebut tentu akan sulit untuk pengelola dalam mengelola laporan-laporan yang masuk perharinya dengan cara konvensional. Pengelola akan sulit dalam mengelompokkan dan menyalurkan laporan warga negara kepada penyelenggara pelayanan publik yang berwenang menanganinya. Keadaan tersebut menyebabkan lambatnya laporan tersebut untuk ditindaklanjuti oleh instansi terkait, untuk saat ini waktu yang dibutuhkan untuk pengelola dalam memverifikasi laporan untuk diteruskan ke penyelenggara pelayanan publik terkait adalah 3 hari kerja (Kementerian Pendayagunaan Aparatur Negara dan Reformasi Birokrasi, n.d.).

Dari 20 data yang diambil secara acak pada aplikasi Lapor! halaman Kota Banjarmasin yang dapat terdapat $70 \%$ laporan yang masuk terdapat kesalahan disposisi oleh admin aplikasi Lapor! Kota Banjarmasin. Hal ini tidak sesuai dengan kebijakan no wrong door policy yang merupakan salah satu

\footnotetext{
1 Kumparan, "Memanfaatkan LAPOR!, Pemkot Banjarmasin Mendapat Penghargaan", diakses dari https://kumparan.com/banjarhits/menjaring-keluhan-berujungpenghargaan pada tanggal 23 Januari 2019 pukul 02:00
} 
latar belakang dibuatnya aplikasi Lapor!. Pengkategorian manual yang harus dipilih oleh pelapor saat melakukan laporan juga dapat menyebabkan kesalahan pemilihan kategori laporan ditambah dengan kategori yang terlalu banyak dan pilihan yang sering tidak selaras dengan keluhan yang ingin dilaporkan oleh pelapor juga dapat menyebabkan kesalahan laporan tersebut untuk diteruskan ke penyelenggara pelayanan publik yang berwenang.

Oleh sebab itu, perlu dikembangkannya prototype pengklasifikasian laporan secara otomatis berdasarkan isi laporan. Salah satu metode dalam klasifikasi teks adalah menggunakan Natural Language Processing (NLP). NLP memiliki beberapa teknik yaitu topic modeling, sentiment analysis, dan information extraction. Dan topic modeling merupakan teknik yang cocok berdasarkan permasalahan yang sudah dijabarkan sebelumnya dimana dataset laporan keluhan masyarakat akan dilakukan feature extraction dan hasilnya akan dilakukan klasifikasi berdasarkan instansi (Young, et al., 2018).

Berdasarkan penelitian terkait terdahulu tentang implementasi Clasification of Indonesian News Articles based on Latent Dirichlet Allocation berhasil melakukan klasifikasi terhadap dokumen berita berbahasa Indonesia dengan metode LDA dengan akurasi rata-rata $70 \%$ terhadap 10 arsip artikel secara keseluruhan sebagai data testing dan pada arsip ke 5 akurasi mencapai $100 \%$ (Kusumaningrum, et al., 2016).

Pada penelitian yang dilakukan $(\mathrm{Li}$, et al., 2011) metode Latent Dirichlet Allocation melakukan klasifikasi terhadap data dengan dimensi yang tinggi dan data dalam teks yang besar menggunakan metode LDA dan SVM juga melakukan perbandingan terhadap metode lainnya dan mendapatkan akurasi sebesar 91.3\%, lebih tinggi dibandingkan metode Weight of Evidence for Text (WET) yang memiliki akurasi $90.3 \%$ dan metode Mutual Information (MI) yang memiliki akurasi $77.8 \%$. Serta, penelitian ini juga menggabungkan metode LDA dan SVM untuk mengklasifikasi dokumen tesk dan mendapatkan macro- $P$ dengan hasil 0.89279 , macro- $R$ dengan hasil 0.889472 , macro-F1 dengan hasil 0.889523 dan micro-F1 dengan hasil 0.890751 yang lebih baik dibandingkan penggabungan metode MI dan SVM dengan hasil macro- $P$ sebesar 0.863596 , macro- $R$ sebesar 0.865328 , macro-F1 sebesar 0.86463 dan micro-F1 sebesar 0.872053. Dimana macro-P merupakan precision sistem secara keseluruhan pada data yang berbeda, macro- $R$ adalah hasil recall sistem secara keseluruhan pada data yang berbeda, macro-F1 adalah hasil perhitungan kombinasi harmonic dari precision dan recall, micro-F1 adalah hasil perhitungan kombinasi individu dari precision dan recall.
Pada penelitian yang dilakukan (Sheshasaayee \& Thailambal, 2017) melakukan perbandingan metode klasifikasi pada konten web dalam bentuk teks dan metode SVM mendapatkan akurasi sebesar $97.40 \%$, lebih tinggi dibandingkan metode Nä̈ve Bayes yang memiliki akurasi sebesar 90.20\% dan metode Random Forest dengan akurasi $88 \%$ dalam melakukan klasifikasi terhadap teks.

Pada penelitian yang dilakukan (Cui, et al., 2014) yang bertujuan untuk mengklasifikasi teks berita dengan melakukan perbandingan metode Nä̈ve Bayes, SVM dan kombinasi LDA dan SVM. Hasilnya kombinasi metode LDA dan SVM mendapatkan nilai presisi sebesar $96.16 \%$, lebih besar dibandingkan metode Nä̈ve Bayes dengan feature extraction yang hanya menghasilkan presisi $69.78 \%$ dan metode SVM dengan feature extraction yang menghasilkan presisi sebesar $94.55 \%$.

Pada penelitian yang dilakukan (George, et al., 2017) yang melakukan survey pada metode klasifikasi dan metode feature extraction dan merujuk pada penelitian terdahulu menyebutkan bahwa kombinasi metode LDA dan SVM menunjukkan performa yang lebih baik dibandingkan kombinasi metode lain seperti Nä̈ve Bayes dan LSA.

Berdasarkan penelitian terkait di atas dapat disimpulkan bahwa metode Latent Dirichlet Allocation dan Support Vector Machine merupakan kombinasi yang menghasilkan performa tinggi dalam mengklasifikasi teks. Oleh karena itu, kombinasi kedua metode tersebut akan diterapkan ke dalam prototype klasifikasi laporan keluhan pelayanan publik berdasarkan instansi untuk mengetahui performa dalam menyelesaikan masalah yang telah dipaparkan.

\section{METODE PENELITIAN}

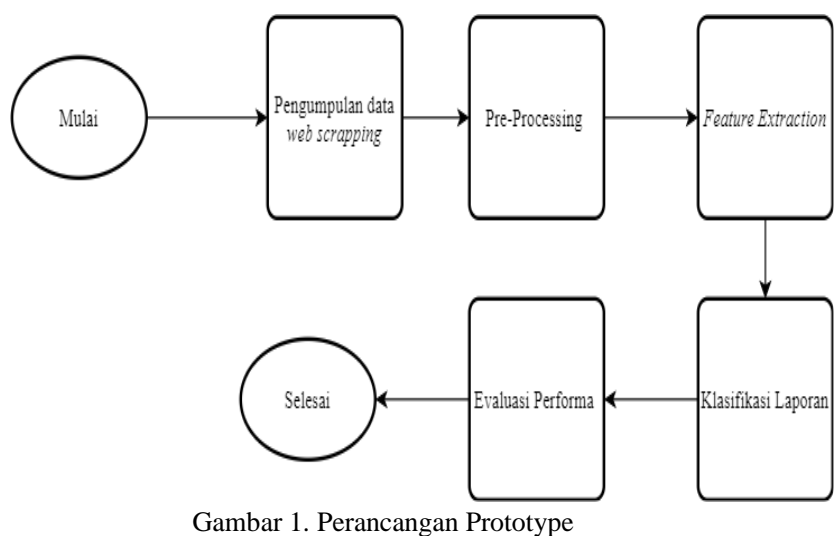

Metode penelitian yang dilakukan pada penelitian ini yang dapat dilihat pada gambar 1 adalah sebagai berikut :

1. Pengambilan Data

2. Text Pre-Processing

3. Feature Extraction 
4. Klasifikasi Laporan

5. Evaluasi Performa

Yang akan dijelaskan pada pont-point berikut :

\subsection{Pengambilan Data}

Pengambilan laporan di aplikasi Lapor! menggunakan teknik web scraping. Web Scraping adalah proses pengumpulan data dan informasi yang berasal dari internet, umumnya halaman website berbasis $H T M L$, secara otomatis dimana data tersebut akan dianalisis sesuai tujuan dan kebutuhan (Slamet, et al., 2018). Tools yang digunakan dalam web scraping ini adalah framework Scrapy dengan bahasa pemrograman Python, Python merupakan bahasa pemrograman interpreter yang merupakan high-level language dan berparadigma object-oriented. Bahasa Pemrograman ini banyak digunakan dalam keperluan machine learning dan hal otomatisasi seperti scraping data (Harrington, 2020).

Scrapy adalah framework berbasis Python yang digunakan dalam melakukan web scraping. Scrapy dapat memudahkan pengguna dalam melakukan scraping data dibandingkan menulis kode scraping dari awal (Loukas, 2016). Dikarenakan website Lapor.go.id kota Banjarmasin membutuhkan pengguna untuk login sebelum melihat detail data laporan dan halaman login berbentuk ajax yaitu teknik yang umum digunakan untuk mengirim dan meminta data ke server secara asynchronous di client-side, maka proses scraping membutuhkan library tambahan untuk membuka browser dan dapat melakukan login secara otomatis. Library tambahan yang digunakan adalah Selenium.

Selenium adalah perangkat lunak yang digunakan untuk melakukan otomatisasi untuk banyak keperluan, seperti melakukan software testing untuk website. Selenium juga mendukung ajax dalam mengirim maupun mendapatkan data (Gojarea, et al., 2015). Sehingga dengan menggunakan Selenium, login di aplikasi Lapor! dapat dilakukan bersamaan dengan proses scraping secara otomatis. Halaman yang akan diproses berada pada url www.lapor.go.id/instansi/pemerintah-kotabanjarmasin-done. Di halaman ini data yang tersedia adalah laporan yang telah selesai dan telah ditutup oleh pengelola dan telah diberi label sesuai instansi yang berwenang. Proses scraping data dapat dilihat pada gambar 2.

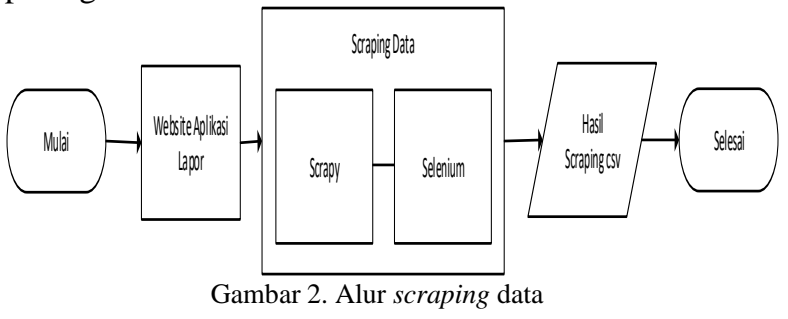

Berikut adalah penjelasan diagram alir proses scraping data:
1. Membuka website aplikasi Lapor! halaman Kota Banjarmasin sebagai sumber data.

2. Proses scraping akan dilakukan dimana didalam proses ini terdapat framework Scrapy sebagai tools untuk mengambil data dan Selenium untuk rekayasa browser untuk melakukan proses seperti klik tombol, menuliskan informasi data untuk melakukan login.

3. Hasil proses scraping data akan disimpan ke dalam bentuk file CSV. Dimana data ini akan menjadi data training dan data testing.

\subsection{Text Pre-Processing}

Text pre-processing adalah proses yang dibutuhkan bagi sebuah data yang berupa teks. Text pre-processing bertujuan agar teks yang diinginkan berkurang kompleksitasnya tanpa mempengaruhi subtansi dan informasi yang terkandung di dalam teks tersebut (Denny \& Spirling, 2018).

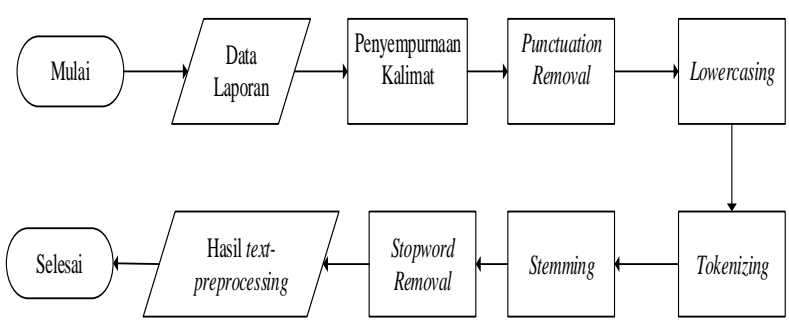

Gambar 3. Alur Text Pre-Processing

Alur text pre-processing pada gambar 3 dimulai ketika data laporan di inputkan.

a. Penyempurnaan Kalimat

Penyempurnaan kalimat pada data dilakukan secara manual untuk menyempurnakan kata yang disingkat atau hilangnya huruf yang membuat kalimat tidak sempurna dan ambigu, lalu diubah dengan kata yang sudah sesuai secara kaidah baik penulisan maupun arti yang sesuai dengan KBBI. Contohnya seperti kata "d" menjadi "di", "ad" menjadi "ada" secara manual.

\section{b. Punctuation removal}

Punctuation removal adalah proses menghilangkan komponen-komponen yang tidak relevan dan tidak mengandung informasi. Seperti tanda baca ("“, "?", ")", "()") dan white space berlebih. Contoh dari punctuation dapat dilihat pada kalimat berikut "benarkah?" menjadi "benarkah".

\section{c. Lowercasing}

Lowercasing yaitu tahap menyamakan semua kalimat dalam teks menjadi huruf kecil. Contoh dari lowercasing dapat dilihat pada kalimat berikut "Lapor" menjadi "lapor". 


\section{d. Tokenizing}

Proses pemotongan kalimat menjadi bagianbagian yang disebut token. Contoh dari tokenizing dapat dilihat pada tabel 1.

Tabel 1. Keluaran dan masukan tokenizing

\begin{tabular}{cc}
\hline Masukan & Keluaran \\
\hline lapor pak tolong & ["lapor", "pak", \\
pak diperiksa hak & "tolong", "pak", \\
kepemilikan tanah & "diperiksa", "hak", \\
dibelakang & "kepemilikan","tanah", "d \\
bangunan sdn & ibelakang", "bangunan", \\
basirih 3 karena & "sdn", "basirih", "3", \\
ilegal listriknya & "karena", "ilegal”, \\
& "listriknya] \\
\hline
\end{tabular}

\section{e. Stemming}

Proses mengubah kata berimbuhan menjadi kata dasar. Contoh dari stemming dapat dilihat pada kalimat "kepemilikan" menjadi "milik".

\section{f. Stopword removal}

Merupakan tahap terakhir pada tahap text preprocessing. Tahap ini akan menghapus kata yang kurang penting dan tidak memiliki informasi yang dibutuhkan. Contoh kata yang termasuk stopword adalah "lah", "kah", "pun", "tah", "ku”, "mu”, "nya" (Tala, 2003).

\subsection{Feature Extraction}

Setelah tahap text pre-processing selesai, tahap berikutnya teks akan dilakukan feature extraction dan pembobotan kata menggunakan metode Latent Dirichlet Allocation (LDA). Latent Dirichlet Allocation (LDA) metode yang diusulkan oleh Blei et al pada tahun 2003 (Blei, et al., 2003) adalah model probabilistik generative dari koleksi data diskrit seperti korpus teks. Ide dasarnya adalah dokumen dipresentasikan sebagai campuran acak topik laten (tidak terlihat), dimana topik-topik ditandai oleh distribusi kata dan LDA akan menganggap bahwa setiap dokumen dapat diwakili oleh distribusi probabilistik topik laten. LDA akan mempresentasikan topik dengan probabilitas kata, dimana kata yang memiliki probabilitas yang paling tinggi di setiap topiknya akan mempresentasikan topik tersebut.

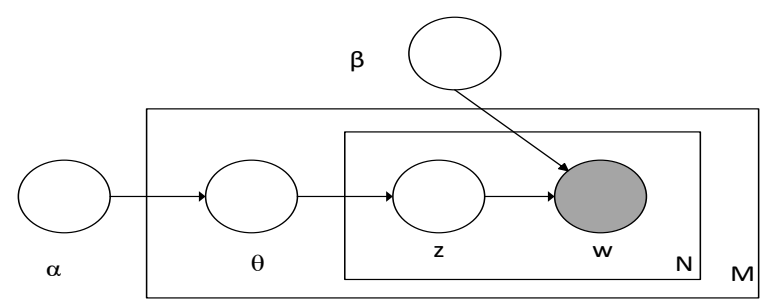

Gambar 4. Grafik representasi model probabilistik LDA

Pada gambar 4 dapat dilihat persegi panjang adalah plates yang menggambarkan replika. Dimana plate terluar menggambarkan dokumen, dan plate di dalam menggambarkan pilihan topik yang berulang dan kata-kata di dalam dokumen. $\alpha$ parameter yang mewakili distribusi topik pada tingkat corpus dalam dokumen, $\beta$ parameter yang mewakili distribusi kata pada tingkat corpus dalam topik.

Metode LDA terdiri dari 2 tahapan. Tahapan pertama yaitu tahap inisialisasi dan tahapan kedua yaitu tahap Gibbs Sampling. Pada tahap inisialisasi, setiap kata unik yang sudah didapatkan dari dokumen diberikan topik secara acak. Selanjutnya pada tahapan kedua, dilakukan iterasi untuk setiap kata menggunakan metode Gibbs Sampling. Untuk mencari perkiraan probabilitas posterian topik pada sebuah kata menggunakan persamaan (1) berikut.

$$
p\left(z_{i}=t \mid z_{-i}, w_{i}\right) \propto \frac{n_{-i, j}^{(w)}+\beta}{n_{-i, t}^{(.)}+W \beta} \frac{n_{-i, t}^{\left(m_{i}\right)}+\alpha}{n_{-i}^{m_{i}}+T \alpha}
$$

Dimana $n_{-i, t}^{(w)}$ adalah jumlah kata $w_{i}$ yang memiliki topik t. $n_{-i, t}^{(.)}$Adalah jumlah total semua kata pada topik t. $n_{-i, t}^{\left(m_{i}\right)}$ adalah jumlah kata yang memiliki topik t pada dokumen $m_{i} . \quad n_{-i}^{m_{i}}$ adalah total kata keseluruhan pada dokumen $m_{i}$.

Setelah batas maksimal iterasi yang ditentukan pada Gibbs Sampling telah tercapai, selanjutnya dilakukan perhitungan nilai $\theta$ (theta) dan nilai $\Phi$ (phi). Tahap ini bertujuan sebagai menentukan pembobotan kata pada isi laporan untuk mengetahui topik apa yang terkandung pada kata di dalam laporan. Hasil yang didapatkan adalah nilai $\theta$ (theta) dimana theta adalah distribusi nilai topik terhadap dokumen dan nilai $\Phi$ (phi) merupakan distribusi nilai kata terhadap topik. Nilai theta ini akan digunakan pada pembobotan dalam melakukan klasifikasi. Untuk menghitung nilai $\theta$ (theta) digunakan persamaan (2) dan untuk menghitung nilai $\Phi$ (phi) menggunakan persamaan (3).

$$
\begin{gathered}
\vartheta^{\left(d_{i}\right)}=\frac{n_{-i, j}^{\left(d_{i}\right)}+\alpha}{n_{-i}^{d_{i}}+T \alpha} \\
\varphi_{j}^{w}=\frac{n_{-i, j}^{(w)}+\beta}{n_{-i, j}^{(.)}+W \beta}
\end{gathered}
$$

Contoh topic modeling pada dataset dengan jumlah tiga topik dapat dilihat pada tabel 2.

Tabel 2. Contoh topic modeling dengan LDA

\begin{tabular}{clll}
\hline Node label & $\begin{array}{l}\text { Topi } \\
\text { k 1 }\end{array}$ & $\begin{array}{l}\text { Topi } \\
\text { k 2 }\end{array}$ & $\begin{array}{l}\text { Topi } \\
\text { k 3 }\end{array}$ \\
\hline $\begin{array}{c}\text { Mohon untuk } \\
\text { ditertibkan parkir- }\end{array}$ & 0.03 & 0.10 & 0.15 \\
parkir liar di & & & \\
sepanjang trotoar & & \\
jalan Belitung Laut & & \\
trotoar yang bagus \\
dan luas digunakan \\
oleh oknum-oknum
\end{tabular}




\begin{tabular}{clll}
\hline Node label & Topi & Topi & Topi \\
& k 1 & k 2 & k 3 \\
\hline $\begin{array}{c}\text { untuk memarkirkan } \\
\text { kendaraannya }\end{array}$ & & \\
\end{tabular}

Klasifikasi akan menggunakan nilai theta yang dihasilkan metode LDA sehingga laporan dapat diklasifikasi berdasarkan label instansi. Contoh dari klasifikasi SVM pada dataset dapat dilihat pada tabel 3.

Tabel 3. Contoh Klasifikasi dengan SVM

\begin{tabular}{|c|c|c|c|c|}
\hline Node label & Topik 1 & Topik 2 & $\begin{array}{c}\text { Topik } \\
\mathbf{3}\end{array}$ & Label \\
\hline $\begin{array}{c}\text { Mohon untuk } \\
\text { ditertibkan parkir- } \\
\text { parkir liar di } \\
\text { sepanjang trotoar } \\
\text { jalan Belitung Laut } \\
\text { trotoar yang bagus } \\
\text { dan luas digunakan } \\
\text { oleh oknum-oknum } \\
\text { untuk memarkirkan } \\
\text { kendaraannya }\end{array}$ & 0.03 & 0.10 & 0.15 & $\begin{array}{c}\text { Dinas } \\
\text { Perhubunga } \\
n\end{array}$ \\
\hline $\begin{array}{c}\text { ingin } \\
\text { menyampaikan } \\
\text { bahwa kegiatan } \\
\text { proyek pembuatan } \\
\text { trotoar di sepanjang } \\
\text { jalan ayani km } 2 \\
\text { sangat asal asalan } \\
\text { banyak yang tidak } \\
\text { dibuatkan saluran } \\
\text { pembuangan air }\end{array}$ & 0.07 & 0.30 & 0.03 & $\begin{array}{c}\text { Dinas } \\
\text { Pekerjaan } \\
\text { Umum dan } \\
\text { Perumahan } \\
\text { Rakyat }\end{array}$ \\
\hline
\end{tabular}

\subsection{Evaluasi Performa}

Evaluasi performa metode menggunakan Confusion Matrix, pengujian dilakukan dengan membandingkan hasil prediksi kombinasi metode LDA dan SVM dengan data laporan masyarakat yang telah didapat sebelumnya (data testing). Dalam melakukan Confusion Matrix dibutuhkan nilai True Positive (TP), True Negative (TN), False Positive (FP), dan False Negative (FN). Dimana matriks yang digunakan adalah accuracy, precision, recall, dan F1 Score.

Untuk data yang kompleks dan non-linear, SVM memiliki teknik yang bernama kernel trick. Dimana kernel akan men-tranformasi data menjadi $\mathrm{N}$ dimensional space. Beberapa kernel yang ada di SVM adalah linear, polynomial, radial basis function (RBF) dan sigmoid. SVM sudah banyak diterapkan dalam studi kasus pengenalan pola dan pengkategorian teks dan menghasilkan akurasi yang sangat tinggi (Sheshasaayee \& Thailambal, 2017)

Kernel SVM yang digunakan pada penelitian adalah kernel Radial Basis merujuk penelitian Kaur Guvir and Kaur Parvinder (Kaur \& Kaur, 2017), kernel Radial Basis merupakan kernel yang menghasilkan akurasi yang baik dalam melakukan klasifikasi teks dibandingkan kernel linear. Kernel Radial Basis Function (RBF) merupakan fungsi yang nilainya tergantung dari jarak asal sebuah data dengan data lainnya di hyperplane. Kernel RBF dapat dihitung menggunakan persamaan (4).

$$
K\left(X_{1}, X_{2}\right)=\operatorname{exponent}\left({ }_{-\gamma}\left\|X_{1}-X_{2}\right\|^{2}\right)
$$

Dimana $\left\|X_{1}-X_{2}\right\|$ merupakan Euclidian distance antara data $X_{1}$ dan data $X_{2}$.

\section{Hasil dan Pembahasan}

\subsection{Pengumpulan dan Pemilahan Data}

Data yang dikumpulkan pada penelitian ini merupakan laporan masyarakat Kota Banjarmasin yang telah diberi label selesai oleh admin aplikasi Lapor!. Pengumpulan data menggunakan teknik scraping dimana teknik ini akan mengambil informasi yang ada pada setiap komponen website Lapor! dalam bentuk HTML. Scrapy yang merupakan framework yang digunakan untuk melakukan proses scraping web Lapor! mengenali setiap komponen HTML pada website menggunakan XPath atau CSS Selector dan Selenium digunakan untuk berinteraksi dengan website Lapor! secara otomatis seperti login dan membuka halaman baru pada saat proses scraping.

Terdapat 1436 jumlah laporan dan 44 jumlah instansi yang terdapat pada data hasil scraping. Persebaran jumlah laporan berdasarkan instansi. Dimana Dinas Pekerjaan Umum dan Perumahan Rakyat merupakan instansi dengan jumlah laporan yang terbanyak dengan jumlah 
449. Berdasarkan penelitian sebelumnya, minimal data yang dibutuhkan untuk setiap sampel guna mendapatkan model yang tidak bias adalah adalah lebih dari 75 data (Beleites, et al., 2012). Oleh karena itu, data yang digunakan untuk klasifikasi pada penelitian ini hanya berasal dari empat instansi yaitu Dinas Pekerjaan Umum dan Perumahan Rakyat, Dinas Perhubungan Kota Banjarmasin, Satpol PP dan Pemadam Kebakaran, dan Dinas Lingkungan Hidup dikarenakan data laporan dari keempat instansi tersebut melebihi 100 laporan. Sehingga setelah proses pemilahan tersebut, jumlah laporan pada dataset berkurang menjadi 1023 laporan.

Proses berikutnya, yaitu menghapus data yang tidak relevan dengan Kota Banjarmasin secara manual. Kesalahan disposisi instansi sejumlah 512 data laporan, sehingga data yang dihasilkan pada tahap ini berjumlah berjumlah 924 data. Dengan rincian yang dapat dilihat pada tabel 4.

Tabel 4. Rincian data beserta instansi

\begin{tabular}{cc}
\hline Masukan & $\begin{array}{c}\text { Kelua } \\
\text { ran }\end{array}$ \\
\hline Dinas Pekerjaan dan Perumahan Rakyat & 449 \\
Dinas Perhubungan Kota Banjarmasin & 213 \\
Satpol PP dan Pemadam Kebakaran & 132 \\
Dinas Lingkungan Hidup & 130 \\
\hline
\end{tabular}

Data tersebut selanjutnya akan diproses di tahap text pre-processing.

\subsection{Implementasi Text Pre-Processing}

Pada tahap ini dilakukan proses preprocessing data yang sebelumnya telah dikumpulkan dan dipilah. Pada proses ini, yang pertama dilakukan adalah melakukan penyempurnaan kalimat secara manual sebelum diproses oleh sistem. Kalimat yang tidak sempurna seperti kalimat yang disingkat, kalimat yang memiliki kesalahan penulisan, kalimat yang tidak sesuai secara kaidah baik penulisan maupun arti yang sesuai dengan KBBI, maupun bahasa daerah yaitu Bahasa Banjar yang tidak ada di KBBI akan diganti dengan kalimat yang memiliki arti yang sama yang sesuai kaidah KBBI.

Setelah kalimat disempurnakan secara manual, kalimat akan diproses menggunakan sistem. Teknologi yang digunakan untuk melakukan textpreprocessing selanjutnya adalah menggunakan bahasa Python disertai dengan library tambahan. Library tambahan tersebut diantaranya adalah NLTK tokenize, Sastrawi StopWordRemoverFactory \& StemmerFactory. Hasil dari text pre-processing bertujuan untuk mengurangi noise dan kompleksitas teks tanpa mempengaruhi subtansi dan informasi yang terkandung dalam teks. Serta dapat meningkatkan performa baik dari segi kecepatan, ketepatan dan akurasi (Denny \& Spirling, 2018) (Kaur \& Buttar, 2016). Pada tabel 5 berikut dapat dilihat hasil dari implementasi text pre-processing.

\begin{tabular}{|c|c|}
\hline Masukan & Keluaran \\
\hline $\begin{array}{l}\text { Saya warga banjarmasjnsangat } \\
\text { mengharapkan segera dibuatkan } \\
\text { jembatan penyebrangan orang } \\
\text { (jpo) di didepan mesjid noor yang } \\
\text { beralamat jalan pangeran samudra } \\
\text { kelurahan kertak ulu banjarmasin } \\
\text { tengah.karena daerah tersebut } \\
\text { sangat ramai yang mau } \\
\text { menyeberang. Karena itu sangat } \\
\text { dibutuhkan jembatan, agar } \\
\text { menyeberang tidak } \\
\text { membahayakan. apakah harus } \\
\text { menunggu jatuh korban baru } \\
\text { dibuatkan jpo.Kami mohon pihak } \\
\text { berwenang menindaklanjutinya. } \\
\text { Terima kasih.. }\end{array}$ & $\begin{array}{l}\text { warga sangat harap segera } \\
\text { buat jembatan } \\
\text { penyebrangan orang jpo } \\
\text { depan mesjid noor alamat } \\
\text { jalan pangeran samudra } \\
\text { lurah kertak ulu tengah } \\
\text { daerah sebut sangat ramai } \\
\text { mau seberang sangat butuh } \\
\text { jembatan seberang bahaya } \\
\text { tunggu jatuh korban baru } \\
\text { buat jpo pihak wenang } \\
\text { menindaklanjutinya }\end{array}$ \\
\hline
\end{tabular}

\subsection{Implementasi Feature Extraction dan Topic Modeling}

Data dari hasil proses text-preprocessing akan dilakukan feature extraction. Feature extraction dilakukan dengan metode Latent Dirichlet Allocation dimana setiap laporan akan dilakukan topic modelling sehingga dapat ditemukan nilai-nilai dimana nilai tersebut akan mewakili topik-topik yang ada pada laporan. Implementasi akan menggunakan library dari Scikit-Learn (Pedregosa, et al., 2011). Sebelum dilakukan topic modeling, laporan akan diproses menjadi vector. Proses mengubah laporan menjadi vector ini akan menggunakan library CountVectorizer dari scikit-learn feature extraction. Sehingga laporan akan menjadi matriks dengan nilai 0 dan 1 seperti tabel 5 berikut.

Tabel 5. Proses mengubah laporan menjadi vector

\begin{tabular}{cc}
\hline Masukan & Keluaran \\
\hline warga sangat harap segera & {$[0,0,0,0,0,0,0,0,0,0,0,0,0$,} \\
buat jembatan & $0,0,0,0,0,0,0,0,0,0,0,0,0,0$, \\
penyebrangan orang jpo & $0,0,0,0,0,0,0,0,0,0,0,0,0,0$, \\
depan mesjid noor alamat & $0,0,0,0,0,0,0$, \\
jalan pangeran samudra & $\ldots \ldots \ldots \ldots \ldots \ldots \ldots \ldots \ldots \ldots \ldots \ldots$ \\
lurah kertak ulu tengah & $0,0,1,0,0,0,0,0,0,0,0,0,0,0$, \\
daerah sebut sangat ramai & $0,0,0,0,0,0,0,0,0,1,0,0,0,0$, \\
mau seberang sangat & $0,0,0,0,0,0,0,0,0,0,0,0,0$, \\
butuh jembatan seberang & 0]$, \\
bahaya tunggu jatuh & \\
korban baru buat jpo & \\
pihak wenang & \\
menindaklanjutinya &
\end{tabular}

Nilai dari vector ini akan dimasukan untuk proses topic modelling mengunakan metode Latent Dirichlet Allocation. Implementasinya akan menggunakan library dari scikit-learn dan akan memudahkan topic modeling laporan tanpa membuat implementasinya dari awal. Proses ini akan menghasilkan nilai theta $\theta$ untuk selanjutnya dilakukan klasifikasi berdasarkan nilai topik dengan jumlah yang telah ditentukan sebelumnya. Untuk percobaan pertama jumlah topik, $\alpha$ (alpha), $\eta$ (eta) dan jumlah iterasi menggunakan nilai bawaan library dari scikit-learn. Dapat dilihat pada tabel 6 hasil masukan dan keluaran dari proses topic modeling menggunakan metode LDA, dimana terdapat 10 topik pada satu laporan. 10 nilai tersebut ditentukan 
berdasarkan jumlah topik, dimana nilai 10 merupakan nilai bawaan untuk jumlah topik dari library scikit-learn.

Tabel 6. Masukan dan keluaran proses topic modeling

\begin{tabular}{cc}
\hline Masukan & Keluaran \\
\hline$[0,0,0,0,0,0,0,0,0,0,0,0,0,0$, & {$[0.002326040 .00232602$} \\
$0,0,0,0,0,0,0,0,0,0,0,0,0,0$, & 0.002326060 .97906514 \\
$\ldots \ldots \ldots \ldots \ldots \ldots \ldots \ldots \ldots \ldots$ & 0.002326550 .00232596 \\
$0,0,0,0,0,0,0,0,0,0,0,0,0,0$, & 0.002326170 .00232608 \\
$0,0,0,0,0,0,0,0]$, & $0.002326060 .0023259]$
\end{tabular}

\subsection{Implementasi Klasifikasi}

Setelah didapatkan nilai topic modeling, selanjutnya akan dilakukan proses klasifikasi berdasarkan instansi. Terdapat empat instansi yang dilakukan klasifikasi, yaitu Dinas Pekerjaan Umum dan Perumahan Rakyat, Dinas Perhubungan Kota Banjarmasin, Satpol PP dan Pemadam Kebakaran, dan Dinas Lingkungan Hidup. Keempat instansi ini akan diubah menjadi angka. Nilai dari setiap label dapat dilihat pada tabel 7 berikut:

Tabel 7. Hasil mengubah nilai label instansi menjadi angka

\begin{tabular}{cc}
\hline Nama Instansi & Nilai \\
\hline Dinas Pekerjaan dan Perumahan Rakyat & 1 \\
Dinas Perhubungan Kota Banjarmasin & 2 \\
Satpol PP dan Pemadam Kebakaran & 3 \\
Dinas Lingkungan Hidup & 4 \\
\hline
\end{tabular}

Lalu dataset akan dibagi dengan rasio 70:30. $70 \%$ sebagai data training model dan 30\% sebagai data testing. Membagi data akan menggunakan library dari scikit-learn model_selection dengan fungsi train_test_split. Impelementasi kode klasifikasi dengan metode Support Vector Machine akan menggunakan library dari scikit-learn svm dengan menggunakan kernel Radial Basis. Untuk percobaan pertama parameter gamma dan c akan menggunakan nilai bawaan dari library.

Data akan melakukan klasifikasi berdasarkan label instansi. Untuk contoh masukan dan hasil prediksi dapat dilihat pada tabel 8 .

Tabel 8. Hasil prediksi klasifikasi

\begin{tabular}{ccc}
\hline Masukan & Keluaran & Label Prediksi \\
\hline$[0.002326040 .00232602$ & 1 & 1 \\
0.002326060 .97906514 & & \\
0.002326550 .00232596 & & \\
0.002326170 .00232608 & & \\
$0.002326060 .0023259]$ & & \\
\hline
\end{tabular}

\subsection{Pengujian Model dan Optimasi Model}

Pada tahap ini akan dilakukan pengujian dan evaluasi performa model dalam menerapkan metode latent dirichlet allocation dan support vector machine terhadap data Lapor! Kota Banjarmasin. Evaluasi performa akan menggunakan Confusion Matrix dengan hasil accuracy, precision, recall, dan
F1 Score. Pada tahap ini juga akan dilakukan percobaan dengan mengubah parameter yang mempengaruhi pada metode, baik metode LDA maupun metode SVM untuk mengetahui apakah ada peningkatan pada performa. Evaluasi performa confusion matrix akan menggunakan dua metode, metode pertama adalah hanya melakukan pemisahan data training dan testing dengan perbandingan 70:30 dan metode kedua adalah metode K-Fold.

Metode K-Fold merupakan metode statistik cross validation yang cocok digunakan untuk data yang sedikit dan k-fold menggunakan semua data untuk di training dan sebagai validasi secara berulang. Terlebih, K-Fold memberikan akurasi yang lebih tinggi dan memberikan bias yang lebih rendah bila dibandingkan metode train-test split (Vabalas, et al., 2019). K-fold bekerja dengan membagi data ke dalam $k$-subset atau fold secara acak dengan jumlah data yang sama pada setiap $k$-subset atau fold. Dimana pada setiap $k$-subset data yang telah didistribusikan akan dibagi menjadi data training dan data testing. Model akan dilatih secara berulang sesuai jumlah k yang ditentukan. Nilai k yang terbaik adalah 5 atau 10 dikarenakan bias data yang akan kecil dan keuntungan dari segi komputasi yang lebih kecil (Kuhn \& Johnson, 2013) (James, et al., 2017). Atas dasar ini penulis akan menggunakan $\mathrm{k}$ dengan nilai 10 .

\section{a. Pengujian Model Percobaan dengan Nilai Bawaan}

Pengujian dilakukan pada model menggunakan parameter bawaan library scikit-learn baik pada metode LDA maupun SVM. Didapatkan akurasi masing-masing pada setiap hasil confusion matrix yang dapat dilihat pada tabel 9 berikut:

Tabel 9. Hasil confusion matrix pada percobaan dengan nilai

bawaan

\begin{tabular}{ccc}
\hline Matrix & Hasil (K-Fold) & $\begin{array}{c}\text { Hasil (training-test split } \\
\mathbf{7 0}: \mathbf{3 0})\end{array}$ \\
\hline accuracy & $55.63 \%$ & $52.51 \%$ \\
precision & $47.98 \%$ & $41.28 \%$ \\
recall & $43.60 \%$ & $39.97 \%$ \\
F1 Score & $41.98 \%$ & $39.97 \%$ \\
\hline
\end{tabular}

\section{b. Optimasi Model}

Merujuk pada beberapa jurnal, mengatakan bahwa hyperparameters (parameter pada metode yang ditentukan sebelum dilakukan training pada data, baik secara manual maupun menggunakan algoritma pencarian sehingga didapatkan hasil yang optimal (Claesen \& Moor, 2015)) dapat memberikan pengaruh besar pada akurasi dalam model melakukan prediksi data, pada dataset yang sama (Wang \& Gong, 2018) (Bardenet, et al., 2013). Bahkan secara umum, hampir semua metode machine learning tidak akan menghasilkan hasil yang optimal jika parameter tidak diatur secara tepat 
(Syarif, et al., 2016). Atas dasar ini maka menulis akan melakukan optimasi model dengan mencari nilai hyperparameters dan diharapkan dapat menaikan akurasi model dalam melakukan prediksi laporan. Optimasi akan dilakukan dengan mencari nilai hyperparameters pada metode latent dirichlet allocationi dan support vector machine.

\section{Optimasi metode Latent Dirichlet Allocation}

Merujuk pada (Blei, et al., 2003) terdapat beberapa parameter yang mempengaruhi performa metode yaitu jumlah iterasi, jumlah topik, $\alpha$ (alpha), dan $\beta$ (beta). Sehingga dengan melakukan percobaan dengan mengubah nilai tersebut dan melakukan percobaan hingga mendapatkan akurasi yang optimal dalam melakukan klasifikasi laporan.

\section{- Jumlah Iterasi}

Jumlah iterasi dibutuhkan setiap dokumen dalam setiap prosesnya hingga proses topic modeling dapat konvergen (Blei, et al., 2003). Merujuk pada jurnal A Prior Setting that Improves LDA in both Document Representation and Topic Extraction (Ding \& Jin, 2019), nilai jumlah iterasi yang digunakan adalah 50. Oleh sebab itu, dalam penelitian ini nilai jumlah iterasi akan menggunakan nilai 50 sebagai nilai awal dalam meningkatkan tingkat akurasi.

\section{- Jumlah topik}

Pada saat menggunakan metode LDA, diharuskan untuk memberikan nilai tetap untuk jumlah topik (Sarkar, et al., 2019), karena jumlah topik dapat memberikan pengaruh pada kualitas topic modeling (Ding \& Jin, 2019) maupun terhadap tingkat akurasi (Arun, et al., 2010). Namun, menentukan nilai topik jadi permasalahan disebabkan tidak adanya metode yang benar-benar tepat dalam menentukan nilai topik (Wallach, et al., 2009). Merujuk Blei et al yang memasukan rentang nilai topik pada klasifikasi dengan nilai 50. Maka, dalam percobaan ini angka yang digunakan akan menggunakan nilai dari percobaan Blei et al (Blei, et al., 2003) sebagai nilai awal dalam meningkatkan akurasi dan akan meningkatkan nilai karena jumlah topik lebih besar lebih baik dibandingkan nilai yang lebih kecil (Wallach, et al., 2009).

\section{- Alpha $(\alpha)$}

Nilai $\alpha$ merupakan salah satu hyper-parameters yang mempengaruhi performa dari metode LDA. $\alpha$ merupakan parameter yang mewakili distribusi topik pada tingkat corpus dalam dokumen pada persebaran topik (Beleites, et al., 2012) (Ding \& Jin, 2019). Merujuk pada On Smoothing and Inference for Topic Models (Asuncion, et al., 2009), nilai alpha yang baik diperlukan untuk menaikan perfroma metode. Nilai $\alpha$ yang digunakan pada penelitian ini adalah 0.1 sebagai nilai awal dalam meningkatkan akurasi metode
(Asuncion, et al., 2009) (Teh, et al., 2007) (Hoffman \& Blei, 2010).

- $\quad \operatorname{Beta}(\beta)$

Nilai $\beta$ merupakan salah satu hyper-parameters yang mempengaruhi performa dari metode LDA. $\beta$ merupakan Parameter yang mewakili distribusi kata pada tingkat corpus dalam topik (Blei, et al., 2003) (Ding \& Jin, 2019). Merujuk pada (Asuncion, et al., 2009), nilai beta yang baik diperlukan untuk menaikan perfroma metode. Merujuk pada (Blei, et al., 2003), untuk mengubah parameter distribusi kata pada beta, maka yang diatur nilainya adalah eta $(\eta)$ yang dapat dilihat pada gambar 6. Eta adalah distribusi kata pada setiap nilai beta (Hoffman \& Blei, 2010).

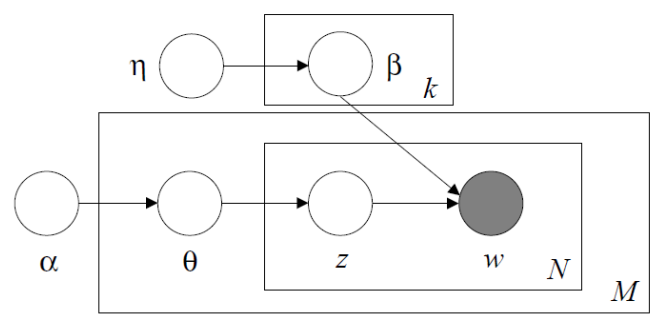

Gambar 6. Representasi model probabilistik LDA yang dihaluskan

Nilai $\eta$ yang digunakan pada penelitian ini adalah 0.1 sebagai nilai awal dalam meningkatkan akurasi metode (Teh, et al., 2007) (Asuncion, et al., 2009) (Hoffman \& Blei, 2010).

\section{Optimasi metode Support Vector Machine}

Optimasi pada metode support vector machine akan dilakukan menggunakan algoritma grid search untuk menentukan hyper-parameters terbaik dalam melakukan klasifikasi data laporan. Grid search merupakan algoritma pencarian penuh berdasarkan sub-set hyper-parameter yang telah ditentukan. Dimana hyper-parameters tersebut ditentukan berdasarkan nilai paling minimal (terendah) sampai ke nilai maksimal (tertinggi). Namun, algoritma ini memerlukan komputasi yang tinggi (Syarif, et al., 2016).

SVM memiliki hyper-parameters yang relatif lebih sedikit dibandingkan metode machine learning lainnya, dan beberapa hyper-parameters bergantung pada kernel yang digunakan, sehingga pencarian optimasi hyper-parameters dapat menggunakan teknik seperti algoritma pencarian (Mantovani, et al., 2015) sehingga penggunaan algoritma grid search akan lebih mudah diterapkan dengan komputasi yang lebih sedikit. Grid search akan selalu dijalankan pada setiap perubahan parameter pada metode LDA sehingga pada metode SVM, dapat menghasilkan akurasi yang optimal pada setiap data hasil topic modeling metode LDA pada saat dilakukan optimasi. C (cost) merupakan hyperparameters pada metode SVM dimana C merupakan nilai yang menentukan jumlah penalti akibat 


\section{Jurnal Teknologi Informasi dan Ilmu Komputer (JTIIK), Vol. 8, No. 6, Desember 2021, hlm. 1265-1276}

kesalahan dalam klasifikasi data. Semakin besar nilai C maka akan memberikan penalti yang besar terhadap kesalahan dalam klasifikasi. Kernel yang digunakan pada penelitian ini adalah kernel radial basis function, dimana pada kernel ini terdapat parameter yang mempengaruhi akurasi yaitu gamma $(\gamma)$ dimana gamma merupakan bagaimana data training dipetakan kedalam ruang input berdimensi tinggi (feature space) dan menentukan bagaimana pengaruh setiap data yang ada (Syarif, et al., 2016) (Kusumaningrum, 2017). Nilai gamma dan C akan dimulai dari 0.001 sampai 10.000 dengan kenaikan nilai 10 .

c. Pengujian model dengan parameter rujukan

Pengujian dilakukan dengan hyperparameters berdasarkan rujukan dari jurnal-jurnal yang telah dipaparkan diatas, hyper-parameters dapat dilihat pada tabel 10 .

Tabel 10. Daftar nilai hyper-parameters rujukan jurnal terkait

\begin{tabular}{ccc}
\hline Matriks & Hyper-parameters) & Nilai \\
\hline \multirow{3}{*}{ LDA } & Alpha & 0.1 \\
& Beta & 0.1 \\
& Jumlah Iterasi & 50 \\
& Jumlah Topik & 50 \\
SVM & C & 10 \\
& Gamma & 1 \\
\hline
\end{tabular}

Hasil performa metode dapat dilihat pada tabel 11.

Tabel 11. Hasil confusion matrix pada percobaan optimasi metode menggunakan hyper-parameters rujukan

\begin{tabular}{ccc}
\hline Matriks & Hasil (K-Fold) & $\begin{array}{c}\text { Hasil (training-test split } \\
\mathbf{7 0}: \mathbf{3 0})\end{array}$ \\
\hline accuracy & $70.33 \%$ & $71.94 \%$ \\
precision & $63.86 \%$ & $68.19 \%$ \\
recall & $60.59 \%$ & $62.73 \%$ \\
F1 Score & $60.46 \%$ & $64.78 \%$ \\
\hline
\end{tabular}

Dapat dilihat terdapat kenaikan performa secara keseluruhan matrix dibandingkan metode yang menggunakan hyper-parameters bawaan scikit-learn.

\subsection{Percobaan Optimasi Model}

Percobaan berikutnya akan dilakukan dengan mengatur hyper-parameters pada metode LDA secara manual dan melihat hasil performa pada saat dilakukan klasifikasi. Pada setiap percobaan dengan dataset yang sudah dipaparkan, hyperparameters SVM selalu didapatkan 10 untuk C dan 1 untuk gamma dari hasil pencarian menggunakan algoritma grid search. Sehingga optimasi metode secara manual hanya pada metode LDA. Hyperparameters rujukan akan menjadi nilai awal dalam menjalankan percobaan dan nilai hyper-parameters yang ditampilkan merupakan perubahan yang menyebabkan peningkatan pada performa metode. Perubahan hyper-parameters akan dihentikan jika terjadi penurunan performa pada saat nilai hyperparameters dinaikan dan diturunkan:

\subsection{Hasil Akurasi Optimasi Model}

Setelah melakukan optimasi metode dengan mengatur nilai hyper-parameter pada metode latent dirichlet allocation dan support vector machine, maka didapatkanlah nilai performa dengan hyperparameters optimal pada dataset metode LDA dengan Jumlah topik $=61$, Jumlah iterasi $=51$, Alpha $(\alpha)=0.6$, Beta $(\beta)=0.001$ dan pada metode SVM C $=10$ dan gamma $(\gamma)=1$ pada metode K-Fold yang dapat dilihat pada Tabel 12 .

Pada metode training-test split 70:30, metode LDA dapat dioptimasi lagi hyper-parameters nya sehingga dapat mendapatkan akurasi sampai $79.85 \%$ dan semua matrix meningkat, namun dengan mengubah nilai hyper-parameters LDA tersebut, hasil pada K-Fold menurun. Nilai hyper-parameters yang digunakan pada metode LDA Jumlah topik = 61 , Jumlah iterasi $=51$, Alpha $(\alpha)=0.6$, Beta $(\beta)=$ 0.001 dan pada metode SVM C $=10$ dan gamma $(\gamma)$ $=1$. Hasil pengujian tanpa K-Fold dapat dilihat pada tabel 12.

Tabel 12. Hasil confusion matrix pada percobaan setelah percobaan dengan optimasi hyper-parameter

\begin{tabular}{ccc}
\hline Matriks & K-Fold & Split-test \\
\hline accuracy & $76.62 \%$ & $79.86 \%$ \\
precision & $76.21 \%$ & $79.98 \%$ \\
recall & $70.73 \%$ & $72.38 \%$ \\
F1 Score & $69.85 \%$ & $74.68 \%$ \\
\hline
\end{tabular}

Berikut salah satu hasil klasifikasi dengan 5 sampel data dengan ketepatan klasifikasi 3 data dan kesalahan klasifikasi 2 data yang dapat dilihat pada tabel 13 berikut :

Tabel 13. Hasil klasifikasi dari sampel data uji

\begin{tabular}{|c|c|c|c|}
\hline Laporan & $\begin{array}{c}\text { Distribusi nilai } \\
\text { topik }\end{array}$ & Label & Prediksi \\
\hline $\begin{array}{c}\text { Tadi saya ikuti } \\
\text { acara lapor } \\
\text { baiman show di } \\
\text { fakultas fisip } \\
\text {... }\end{array}$ & $\begin{array}{c}{[0.01315789} \\
0.03508772 \\
\ldots \ldots \ldots \ldots \ldots \ldots \\
0.01315789 \\
0.01315789]\end{array}$ & $\begin{array}{l}1 \text { (Dinas } \\
\text { Pekerjaan dan } \\
\text { Perumahan } \\
\text { Rakyat) }\end{array}$ & $\begin{array}{c}1 \text { (Dinas } \\
\text { Pekerjaan } \\
\text { dan } \\
\text { Perumahan } \\
\text { Rakyat) }\end{array}$ \\
\hline $\begin{array}{l}\text { Saya ingin } \\
\text { melaporkan } \\
\text { mengenai } \\
\text { lampu traffic } \\
\text { light ... }\end{array}$ & $\begin{array}{c}{[0.01209974} \\
0.01119403 \\
\ldots \ldots \ldots \ldots \\
0.01119403 \\
0.01217532]\end{array}$ & $\begin{array}{c}2 \text { (Dinas } \\
\text { Perhubungan } \\
\text { Kota } \\
\text { Banjarmasin) }\end{array}$ & $\begin{array}{c}3 \text { (Satpol PP } \\
\text { dan } \\
\text { Pemadam } \\
\text { Kebakaran) }\end{array}$ \\
\hline $\begin{array}{c}\text { Kami warga } \\
\text { kelurahan surgi } \\
\text { mufti mengadu } \\
\ldots .\end{array}$ & $\begin{array}{c}{[0.01209677} \\
0.01209677 \\
\ldots \ldots \ldots \ldots \ldots \\
0.01209677 \\
0.01227708]\end{array}$ & $\begin{array}{l}4 \text { (Dinas } \\
\text { Lingkungan } \\
\text { Hidup) }\end{array}$ & $\begin{array}{c}4 \text { (Dinas } \\
\text { Lingkungan } \\
\text { Hidup) }\end{array}$ \\
\hline $\begin{array}{l}\text { Kepada yth } \\
\text { dinas pupr kota } \\
\text { banjarmasin } \\
\text { saya ingin } \\
\text { melaporkan.... }\end{array}$ & $\begin{array}{c}{[0.00670992} \\
0.02748414 \\
\ldots \ldots \ldots \ldots \ldots \\
0.01691332 \\
0.03993109]\end{array}$ & $\begin{array}{l}1 \text { (Dinas } \\
\text { Pekerjaan dan } \\
\text { Perumahan } \\
\text { Rakyat) }\end{array}$ & $\begin{array}{l}1 \text { (Dinas } \\
\text { Pekerjaan } \\
\text { dan } \\
\text { Perumahan } \\
\text { Rakyat) }\end{array}$ \\
\hline $\begin{array}{l}\text { Malam minggu } \\
\text { saya bawa } \\
\text { keluarga ke } \\
\text { siring bekantan } \\
\text { mau santai .... }\end{array}$ & $\begin{array}{c}{[0.01287554} \\
0.03433476 \\
\ldots \ldots \ldots \ldots \ldots \\
0.01307748 \\
0.04494619] \\
\end{array}$ & $\begin{array}{c}3 \text { (Satpol PP } \\
\text { dan Pemadam } \\
\text { Kebakaran) }\end{array}$ & $\begin{array}{l}1 \text { (Dinas } \\
\text { Pekerjaan } \\
\text { dan } \\
\text { Perumahan } \\
\text { Rakyat) }\end{array}$ \\
\hline
\end{tabular}




\section{KESIMPULAN DAN SARAN}

\subsection{KESIMPULAN}

Berdasarkan dengan penelitian yang telah dilakukan adapun simpulan yang dapat ditarik adalah sebagai berikut:

1. Dapat dibangunnya prototipe berbentuk webservice yang dibangun menggunakan bahasa pemrograman Python dengan framework Masonite. Pada proses feature extraction digunakan metode LDA topic modeling dan pada proses klasifikasi digunakan metode SVM menggunakan library Scikit-learn.

2. Penerapan Metode LDA dan SVM dapat mengklasifikasikan data uji laporan dengan benar sesuai instansi dengan performa yamg cukup baik yaitu accuracy sebesar $76.18 \%$, precision sebesar $75.78 \%$, recall sebesar $70.44 \%$ dan F1 Score sebesar $69.36 \%$ dengan menggunakan K-Fold dengan Fold berjumlah 10. Dan accuracy sebesar 79.85\%, precision sebesar $79.98 \%$, recall sebesar $72.37 \%$ dan F1 Score sebesar $74.67 \%$ training-test split $70: 30$.

\subsection{SARAN}

Adapun saran yang dapat diberikan oleh peneliti adalah sebagai berikut:

1. Menambahkan data training menjadi lebih banyak sehingga model dapat memberikan performa yang lebih baik.

2. Menambahkan data yang lebih seragam dan jumlah laporan lebih terdistribusi dengan baik per-instasi. Sehingga klasifikasi dapat dilakukan pada semua instansi.

3. Terdapat fungsi yang dapat mengubah kalimat ber-bahasa daerah secara otomatis tanpa diubah secara manual.

\section{DAFTAR PUSTAKA}

ARUN, R., SURESH, V., MADHAVAN, C. E. V. \& MURTY, M. N., 2010. On Finding the Natural Number of Topics with. Berlin, s.n.

ASUNCION, A., WELLING, M., SMYTH, P. \& TEH, Y. W., 2009. On Smoothing and Inference for Topic Models. Montreal, s.n.

BARDENET, R., BRENDEL, M., KEGL, B. \& SEBAG, M., 2013. Collaborative hyperparameter tuning. Atlanta, s.n.

BELEITES, C. dkk., 2012. Sample Size Planning for Classification Models. Analytica Chimica Acta, Volume 760, pp. 25-33.

BLEI, M. D., NG, Y. A. \& JORDAN, I. M., 2003. Latent Dirichlet Allocation. Journal of Machine Learning Research, Volume 3, pp. 993-1022.

CLAESEN, M. \& MOOR, B. D., 2015. Hyperparameter Search in Machine Learning. Agadir, s.n.
CUI, L. dkk., 2014. A Hierarchy Method Based on LDA and SVM for News Classification. IEEE International Conference on Data Mining Workshop, Volume 2015, pp. 60-64.

DENNY, M. J. \& SPIRLING, A., 2018. Text Preprocessing For Unsupervised Learning: Why It. Political Analysis, 26(2), pp. 168-189.

DING, J. \& JIN, W., 2019. A Prior Setting that Improves LDA in both Document Representation and Topic Extraction. Budapest, s.n.

GEORGE, M., SOUNDARABAI, B. \& KRISHNAMURTHI, K., 2017. Impact of Topic Modelling Methods and Text Classification Techniques in Text Mining: a Survey. International Journal of Advances in Electronics and Computer Science, 4(3).

GOJAREA, S., JOSHI, R. \& GAIGAWARE, D., 2015. Analysis and Design of Selenium WebDriver Automation Testing. 2nd International Symposium on Big Data and Cloud Computing (ISBCC'15), Volume 50, pp. 341-346.

HARRINGTON, A. N., 2020. Hands-on Python Tutorial. Chicago: Loyola University of Chicago.

HOFFMAN, M. D. \& BLEI, D. M., 2010. Online Learning for Latent Dirichlet Allocation. Advances in Neural Information Processing Systems, Volume 23, pp. 856-864.

JAMES, G., WITTEN, D., HASTIE, T. \& TIBSHIRANI, R., 2017. An Introduction to Statistical Learnin with Applications in $R$. New York: Springer Science+Business.

KAUR, G. \& KAUR, E. P., 2017. Novel Approach of Text Classification by SVM-RBF Kernel and Linear SVC. International journal of Advance Research, Ideas, and Inovations in Technology, 3(3).

KAUR, J. \& BUTTAR, P. K., 2016. A Systematic Review on Stopword Removal Algorithms. International Journal on Future Revolution in Computer Science \& Communication Engineering, 150(4), pp. 15-17.

Kementerian Pendayagunaan Aparatur Negara dan Reformasi Birokrasi, n.d. Lapor!. [Online] Available at: https://www.lapor.go.id/ [Accessed 2911 2019].

Kementerian Pendayagunaan Aparatur Negara dan Reformasi Birokrasi, n.d. Tentang LAPOR!. [Online]

Available at: https://www.lapor.go.id/tentang [Accessed 2911 2019].

KUHN, M. \& JOHNSON, K., 2013. Over-Fitting and Model Tuning. In: Applied Predictive Modeling. New York: Springer Science+Business, pp. 69-71.

KUSUMANINGRUM, A. P., 2017. Optimization of Support Vector Machine Parameters Using 
1276 Jurnal Teknologi Informasi dan Ilmu Komputer (JTIIK), Vol. 8, No. 6, Desember 2021, hlm. 1265-1276

Genetic Algorithm For Microarray Data Classification. s.1., s.n.

KUSUMANINGRUM, R., WIEDJAYANTO, M., ADHY, S. \& SURYONO, S., 2016. Classification of Indonesian News Articles based on Latent Dirichlet. in Proceedings of the 2016 International Conference on Data and Software Engineering (ICoDSE).

LI, K. dkk., 2011. Multi-class text categorization based on LDA and SVM. Procedia Engineering, Volume 15, pp. 1963-1967.

LOUKAS, D. K., 2016. Learning Scrapy. Birmingham: Packt Publishing.

MANTOVANI, R. G. dkk., 2015. Effectiveness of Random Search in SVM hyper-parameter tuning. Killarney, s.n.

MARYAM, N. S., 2016. Mewujudkan Good Governance Melalui Pelayanan Publik. Jurnal Ilmu Politik dan Komunikasi, VI(1), p. 2.

MEGAWATI, C., 2015. Analisis Aspirasi dan Pengaduan Di Situs Lapor! dengan Menggunakan Text Mining. pp. 1-3.

OBSORNE, D. \& GAEBLER, T., 1992. Dalam: Reinventing Government. California: Addison-Wesley Publ. Co.,, p. 24.

PEDREGOSA, F. dkk., 2011. Scikit-learn: Machine Learning in Python. Journal of Machine Learning Research, Volume 12, pp. 28252830.

SAGGAF, S., SAID, M. M. \& SAGGAF, W. S., 2018. Dalam: Reformasi Pelayanan Publik di Negara Berkembang. s.1.:SAH MEDIA, pp. 26-27.

SARKAR, S. dkk., 2019. Application of Optimized Machine Learning Techniques for Prediction of Occupational Accidents. Computers and Operations Research, Volume 106, pp. 210224.

SHESHASAAYEE, A. \& THAILAMBAL, G., 2017. Comparison of Classification Algorithms in
Text Mining. International Journal of Pure and Applied Mathematics, 116(22), pp. 425433.

SLAMET, C. dkk., 2018. Web Scraping and Naïve Bayes Classification for Job Search Engine. IOP Conference Series: Materials Science and Engineering, Volume 288.

SYARIF, I., WILLS, G. \& BENNET, A. P., 2016. SVM Parameter Optimization using Grid Search and Genetic Algorithm to Improve Classification Performance. Telecommunication Computing Electronics and Control (TELKOMNIKA), 14(4), pp. 1502-1509.

TALA, F. Z., 2003. A Study of Stemming Effects on Information Retrieval in Bahasa Indonesia.

TEH, Y. W., NEWMAN, D. \& WELLING, M., 2007. A Collapsed Variational Bayesian Inference. Vancouver, s.n.

VABALAS, A., GOWEN, E., POLIAKOFF, E. \& CASSON, A. J., 2019. Machine learning algorithm validation with a Limited Size Sample. Plos Name, 14(11).

WALLACH, H. M., MIMNO, D. \& MCCALLUM, A., 2009. Rethinking LDA: Why Priors Matter. Vancouver, s.n.

WANG, B. \& GONG, N. Z., 2018. Stealing Hyperparameters in Machine Learning. IEEE Symposium on Security and Privacy, pp. 3652.

YOUNG, T., HAZARIKA, D., PORIA, S. \& CAMBRIA, E., 2018. Recent Trends in Deep Learning Based Natural Language Processing. IEEE Computational Intelligence Magazine, 13(3), pp. 55-75. 